Hanna Zalewska-Jura (Łódź)

\title{
Pro Bessarione poeta ${ }^{1}$
}

$\mathrm{B}$ essarion, a Cardinal Bishop, was one of the most illustrious Greek scholars of the fifteenth century: a church hierarch, theologian, intellectual and a humanist. As a high-ranking member of the clergy, hailing from the Pontic Greek city of Trebizond, the capital of the Empire of Trebizond (founded in 1204), he worked hard to bring about reunion between the Orthodox Church and the Roman Catholic Church. This is well evidenced by his numerous works devoted to theoretical and practical aspects of reunification between these two Churches. As an expert in ancient Greek philosophy he searched for ways to reconcile the ideas of Plato and Aristotle and performed an exegesis of Platonism in the spirit of Christianity. His philosophical and theological treatises on the aforementioned subject constitute an important part of the literary heritage of the Cardinal. As one of the most learned scholars and humanists of his times, whose purpose was to combine classical and Christian traditions, he founded an intellectual center, the so-called Academy of Bessarion (Accademia Bessarionea) in Rome, which assembled Roman intellectuals of the Renaissance. He himself translated a few notable works of Greek literature into Latin, such as Aristotle's Metaphysics and Xenophon's Memorabilia. His private library, the biggest in those times, with approximately 900 manuscripts, was bestowed by him to the Venetians. His collection became the foundation of today's Bibliotheca Nazionale Marciana in Venice 2 .

While the philosophical, theological and historical works by Bessarion are now the subject of interest of many researchers in Byzantine studies, representing different scientific fields, his poetic works are not being considered with sufficient

\footnotetext{
${ }^{1}$ A paraphrase of the famous defense speech by Cicero Pro Archia poeta.

${ }^{2}$ Life and works of Bessarion have been described in a considerable number of biographical books. It suffices to recall here only some of the studies in the field: e.g. A. BANDINI, De vita et rebus gestis Bessarionis cardinalis Nicaeni. Commentarius, Romae 1777; H. VAST, Le cardinal Bessarion (1403-1472). Étude sur la Chrétienté et la Renaissance vers le Milieu du XVe siècle, Paris 1878; L. Mohlen, Kardinal Bessarion als Theologe, Humianist und Staatsman, vol. I-III, Paderborn 1923-1942; L. Labowsky, Bessarion's Library and the Biblioteca Marciana, Rome 1979; G.L. Coluccia, Basilio Bessarione. Lo spirito Greco e l'occidente, Firenze 2009; J. Monfasani, Bessarion Scholasticus. A study of cardinal Bessarion's Latin library, Turnhout 2012. Cf. also »Inter Graecos latinissimus, inter Latinos graecissimus «. Bessarion zwischen den Kulturen, ed. C. Martl, C. Kaiser, T. Ricklin (Pluralisierung \& Autoritat, 39), Berlin 2013.
} 
attention. There are likely several reasons for this. Above all, poetic works constitute only a marginal part of the corpus of Bessarion's works. From the contemporary epistemic point of view, their value can hardly be affirmed, if we compare their content with the deep tenor found in intellectual's deliberations in his philosophical and theological works. All the poems are occasional in their character; they are limited to funeral themes and to illustrious people of those times ${ }^{3}$. Moreover, almost all of them ${ }^{4}$ are Bessarion's early writings, which is confirmed by the Marcianus Gr. 533 (778), including a compendium of his juvenile works preceded by his autograph ${ }^{5}$. For example, his monody on the death of Manuel II Palaeologus was probably written soon after the emperor's passing in 1425, when Bessarion was about twenty two years old ${ }^{6}$. The monothematic character of such poetry, combined with the characteristics of paradigmatic threnody, make these literary works less attractive for readers - and the research possibilities significantly restricted. The value of Bessarion's poems is called into question because many scholars share the common opinion about his artistic immaturity, related to his young age at the time when he wrote these particular works. Therefore, Bessarion's poetry is not an issue commonly discussed by the experts in the field.

Some of Bessarion's literary works are a testimony of his relations with the court of the rulers of his hometown, Trebizond ${ }^{7}$. After the departure from the city to Constantinople (ca. 1417), the intellectual returned to Trebizond at least once ${ }^{8}$, and stayed there from 1426 to 1427 with the mission to create a common antiTurkish coalition of the two emperors - John VIII Palaeologus and Alexius IV

\footnotetext{
${ }^{3}$ Thesaurus Linguae Grecae includes the following works by Bessarion: Monodia in Manuelem Paleologum, Monodiae tres in Theodoram Comnenam, Versus epitaphii ad imperatricem Theodoram Paleologinam, Versus ad duplices togas Manuelis et Helenae Paleologorum, Monodia in imperatricem Cleopam Paleologinam, Versus epitaphii in imperatricem Cleopam Paleologinam, Versus epitaphii in Michaelum Amirutzem, Versus epitaphii in Plethonem.

${ }^{4}$ Versus epitaphii in Plethonem is an exception, as its terminus post quem is the approximate date of Plethon's (1452-1454) death.

${ }^{5}$ See H.-D. SAFFrey, Recherches sur quelques autographes du cardinal Bessarion et leur caractère autobiographique, [in:] Mélanges Eugène Tisserant, vol. III, Cité du Vatican 1964, p. 279-292.

${ }^{6}$ The date of Bessarion's birth is still controversial. The dates proposed by the researchers show a high range and oscillates between 1393 to 1408 . The most often repeated date is the $2^{\text {nd }}$ January 1403 . See G.L. Collucia, op. cit., p. 3; cf. M. Salamon, Bessarion, [in:] Religia. Encyklopedia PWN, vol. II, Warszawa 2001, p. 47. A.-M. TALвот, Bessarion, [in:] ODB, vol. I, p. 285 has 1399/1400.

${ }^{7}$ S.P. Karpov, a Russian scholar of the history of Trebizond, mentions all the works of Bessarion related to his hometown - С.П. КАрПов, История Трапезундской Империи, Санкт-Петербург 2007, p. 464-465. Bessarion's juvenile works (including the Trapezuntine ones) were described by E.J. Stormon, Bessarion before the Council of Florence. A survey of early writings (1423-1437), [in:] Byzantine Papers. Proceedings of the First Australian Byzantine Studies Conference, Canberra, 17-19 May 1978, ed. E. Jeffreys, M. Jeffreys, A.M. Moffatt, Canberra 1981, p. 128-156.

${ }^{8}$ L. Mohler, publisher of Cardinal's works, hypothesised that Bessarion visited the Empire of Trebizond again in 1436, at the request of the Byzantine emperor John VIII Palaiologus due to the planned Council of Ferrara. L. MoHLER, op. cit., Bd. I, Paderborn 1923, p. 54.
} 
Megas Comnenus. On the occasion of the arrival to the Trapezuntine court of the Grand Comneni he composed an Address ${ }^{9}$ to the Emperor Alexius IV; subsequently, he created the three monodies for the death of Theodora Comnena. Three consolatory speeches are also associated with the dynasty of Grand Comneni, as they have been written for the Byzantine emperor John VIII Palaiologos after the death of his wife Maria Comnena, the daughter of Alexius IV and Theodora ${ }^{10}$.

Filippo Maria Pontani, the author of the article Epicedi inediti del Bessarione, is one of the few researchers who made an attempt to face and examine these works ${ }^{11}$, as he analysed the three monodies on the death of Theodora Comnena ${ }^{12}$. He examined the visual and graphic aspects of the manuscript with the aforementioned epicedia found in Marcianus Gr. 533. He then analysed the content and the artistic style of the poems, putting emphasis primarily on intertextualities and cryptocitations from ancient literary works and from the Bible, in order to reach the meaningful conclusion:

Sul piano stilistico, sono da sottolineare l'enfasi delle frasi esclamative e delle interrogative
retoriche, che toccato punte di stucchevole intemperanza; e in genere l'effusività, la replica
degli stilemi, la manierata organatura di molte frasi e cadenze. Un notevole studio sembra
posto nel sostenere il piú (talora fino al $\pi v i \tilde{\gamma}$ ) ) làmbito dei periodi, come per una prova
di abilità e di padronanza oratoria di frassegio. Indipendentemente dai riscontri puntuali con
fonti stilistiche classiche e postclassiche, che non mette il conto di fare, non si può non sotto-
lineare la disinvolta e talora ardita assimilazione che è alla base di questa scrittura; essa non
tocca quasi mai la sfera dell'arte, giacché gli epicedi restano sul piano dell'esercizio di scuola
e dello sfoggio d'occasione, ma va riconosiuta come qualità positiva d'un retore «umanista» ${ }^{13}$.

The negative opinion given by the Italian researcher on the poetic talent of young Bessarion surely provokes a discussion. We might agree with F.M. Pontani's point of view as far as the meaning of literary incrustations found in monodies is concerned, however the fact that he regards them as the main and basic artistic value of the poems seems at least questionable; but the fact of calling them just 'scholastic exercise and incidental show' is definitely controversial. Pontani's opinion

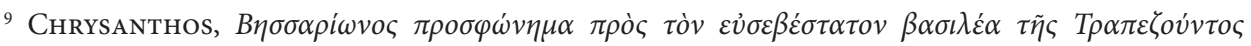

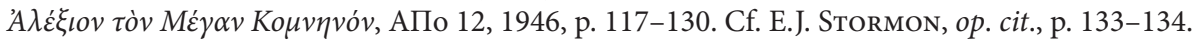

${ }^{10}$ Maria Megale Comnena married Byzantine emperor John VIII in August 1427; he died on 17 December 1439. The consolatory speeches of Bessarion were created no earlier than in 1440. To date, only the first of the speeches has been edited. A. Gentilini, Una consolatoria inedita del Bessarione, [in:] Scritti in onore di Carlo Diano, Bologna 1975, p. 149-164. Cf. E.J. Stormon, op. cit., p. 134-135.

${ }^{11}$ F.M. Pontani, Epicedi inediti del Bessarione, RSBN 5, 1968, p. 105-121.

${ }^{12}$ Theodora Comnena from the Cantacuzene family, the wife of Alexius IV Megas Comnenus, the Empress of Trebizond in the years 1412-1426.

${ }^{13} \mathrm{Ibidem}, \mathrm{p} .108$. L. Colluccia shared Pontani's opinion and found the monodies on Thedora Comnena banal, op. cit., p. 18. The polemical attitude is presented by S. RoNCHEY, Bessarione poeta e l'ultima corte di Bisanzio, [in:] Bessarione e l'Umanesimo. Catalogo della mostra (Venezia, Biblioteca Nazionale Marciana, 27 Aprile - 31 Maggio 1994), ed. G. FiacCAdori, Napoli 1994, p. 49.
} 
was probably based on modern aesthetic qualifiers, while the cultural, artistic and intellectual background of the Byzantine Empire in the $15^{\text {th }}$ century was not taken into consideration. In my article I will make an attempt to reinterpret the three monodies on the death of Theodora Comnena and examine them from the formal, compositional and poetical perspective, with an aim of revising this unfair, in my opinion, assessment of Bessarion's poetry ${ }^{14}$.

The precise date and chronology in which the discussed epicedia were written is not known. The death of the Empress, on the 12 November $1426^{15}$, should be recognised as terminus post quem. Despite apparent spontaneity - àv $\tau \grave{i} \delta \varepsilon \tau \tilde{\omega} v$

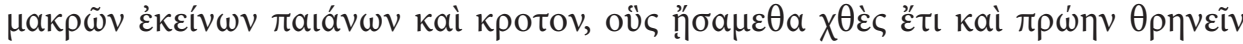

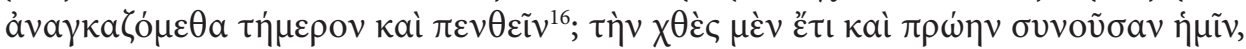
$\nu \tilde{v} v \delta^{\prime} \dot{\varepsilon} \xi \dot{\eta} \mu \tilde{\omega} v \gamma_{\varepsilon} v o \mu \dot{\varepsilon} v \eta v^{17}$, typical for this particular literary genre, the poems were not written immediately. The author needed more time to write such long and well-studied works. The circumstances in which the monodies were written are also dubious and need further examination. We may presume that their public presentations, if there were any, took place during court ceremonies on the anniversary of Theodora's death. If the assumption is correct, the hypothesis that the epicedia were written within one or two years after the Empress's passing, but not earlier than in 1426, seems reasonable. The reminiscences of the burial ceremony

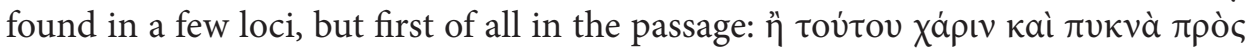

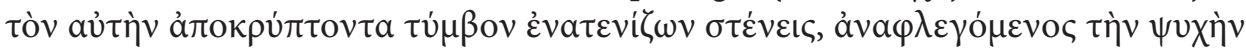

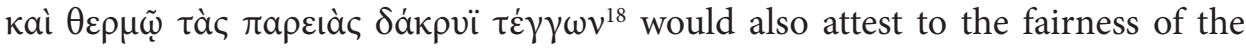
conclusions.

The genealogical classification of Bessarion's works is based on the meaning of the word "monody", repeatedly used by the author in his poems' titles: I) $\mu$ ov $\omega \delta$ ía

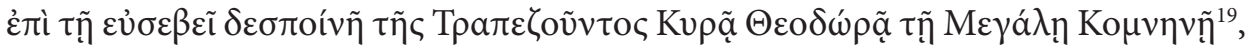

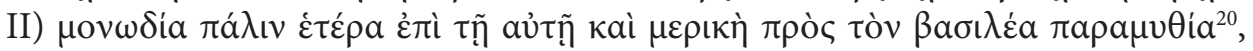

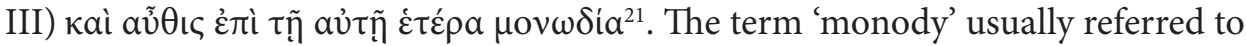
a speech in which one person lamented another's death (view held by the modern

\footnotetext{
${ }^{14}$ The text of the first monody after: A. Sideras, Die byzantinischen Grabreden: Prosopographie, Datierung, Überlieferung, Wien 1994 (cetera: Bessarion, I), p. 531-536, of the second and the third: IDEM, 25 Unedierte byzantinische Grabreden, Thessalonica 1990 (cetera: BessarIon, II/III), p. 351-359 and 363-368. In the following references the numbers of the poem, the page and verse are given in notes.

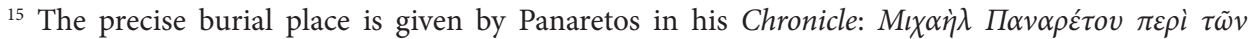

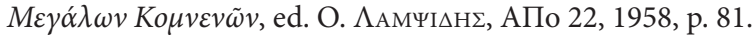

${ }^{16}$ Bessarion, I, 531, 15-17.

${ }^{17}$ Bessarion, II, 363, 8-9.

${ }^{18}$ Bessarion, III, 367, 16-18. Other relevant passages e.g. I, 352, 24-25, or III, 366, 16-23.

${ }^{19}$ Pinax: $\varepsilon^{\prime}$, H.D. SAfFrey, op. cit., p. 285.

${ }^{20}$ Pinax: $\varsigma^{\prime}$, l. cit.

${ }^{21}$ Pinax: $\zeta$, l. cit.
} 
Byzantinists) ${ }^{22}$. The monodies on Theodora Comnena's passing, although presumably ${ }^{23}$ written in prose, still represent the features of classical poesis docta, as far as their character and poetic style are concerned. These monodies nowadays would be classified as poetic prose. It seems hard to believe that Bessarion, an erudite and an expert on ancient Greek literature, was not aware of the etymological meaning of the word 'monody', uniting both the elements of poetry and music, and applied this term only according to the linguistic habits of his times. While there are no reasons to question the literary genre of the poems, their value shall be estimated by the aesthetic norms typical for the poetry, not only for the rhetoric.

Each of the three epicedia may be regarded as a whole. Each of them contains the elements that are distinctive for the funeral poems - comploratio (lamentatio), laudatio, consolatio ${ }^{24}$, and that makes them typical examples of this particular literary genre. A more detailed presentation of the content of all the monodies would exceed the scope of this article, especially when we deal with texts that cannot be properly described in narrative form. It should be stated that all the monodies follow a threefold compositional scheme: in the beginning and in the end of the poems there are laments and laudations of the deceased, the passages in the middle include parenetical strands and have a consolatory role. The whole series make a perfect harmonic triptych structure due to the dominant themes: lamentations and laudations in the first and in the third monody and consolation in the second. The compositional symmetry present in each monody in the triptych form is significantly intensified. Such an elaborate structure certainly could not have been accidental. It was thoroughly thought out and laid out, especially since it is said that there was yet another poem on the death of Theodora Comnena. In the Mar-

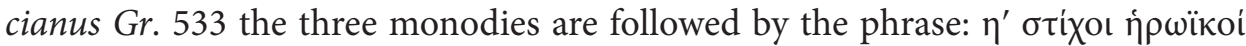

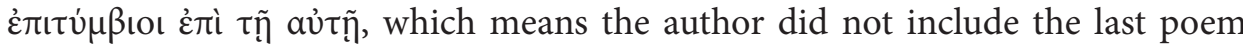
in the cycle of monodies. Unfortunately, the codex in this place is damaged and the poem is unreadable ${ }^{25}$.

The first monody, full of mourning and the feelings of irreplaceable loss after the death of the Empress, is dominated by sentimental laments. The stylised spontaneity of experiences is demonstrated by many exclamations used by the author to describe these feelings and various rhetorical questions that depict the sense of helplessness and despair. The poem starts with an exclamation:" $\Omega \tau \tilde{\eta} \varsigma \dot{\alpha} \tau \dot{\alpha} \kappa \tau$ ov

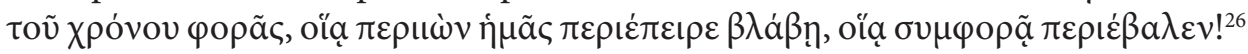

\footnotetext{
${ }^{22}$ F.M. Pontani, op. cit., p. 106; S. Ronchey, op. cit., p. 48-49.

${ }^{23}$ The specificity of the Byzantine versification systems and the practices of writing manuscripts does not allow to confirm with certainty that we are not dealing with poetry sensu stricto; See E. WeLLESz, Historia muzyki i hymnografii bizantyjskiej, trans. M. KAZIŃsKI, Kraków 2006, p. 96 and O. JUREwiCZ, Historia literatury bizantyńskiej. Zarys, Wrocław 1984, p. 82.

${ }^{24}$ S. ZAвŁоскі, Antyczne epicedium i elegia żałobna. Geneza i rozwój, Warszawa 1965, p. 5-6.

${ }^{25}$ F. Pontani, op. cit., p. 105.

${ }^{26}$ Bessarion, I, 531, 4-5.
} 
and ends in a similar way: $\ddot{\omega} \sigma v \mu \varphi о \rho a \tilde{c} !^{27}$. The noun $\sigma v \mu \varphi о \rho a ́$ 'unhappiness', appearing in both exclamations, $n . b$. giving the effect of a ring composition, synthesises the atmosphere of the monody. The praises of Theodora justify and explain to the collective lyrical subject the bitter feeling of loss and at the same time they are aimed at assuaging the emotions, to counterbalance the violent manifestations of despair. The remarks on the precarious nature of human existence, ephemeral time and inevitable death have the same function in the poem's composition. They are a sort of consolation with its cacumen in the middle part of the poem in the form of parenetical reflections on the God's will being done, despite the mortals' lack of understanding.

The motif of comploratio also prevails in the third monody, but the forms of despair seem more moderate. The words or $\gamma \tilde{n} \delta \alpha \kappa \rho v i \sigma \omega^{28}$ announce the change of the poem's tone. The feeling of despair is substituted here with the sense of sorrow and grief; the theme of the poem is not so much the Empress's death, but rather the fate of her bereft subjects. The praised virtues of the Empress, found among the words of complaint, make the feeling of emptiness even greater, similarly to the first monody. The axis of the symmetrical structure of the poem is found in the words of consolation, in the Christian spirit: for those who live in harmony with Christ, death is not death, but just a departure ${ }^{29}$.

The second monody significantly differs from the other two, both in size (it is the longest one), as well as in the form of composition and the content. The introductory part of the laments, built on a series of rhetorical questions, smoothly proceeds to the panegyric part about Theodora's virtues and benevolence, constantly demonstrated by unabated despair of her people. Bessarion found his source of consolation in the evangelical story of the crucifixion of Christ and his sacrifice for the good of humanity. The exegesis of the twice cited ${ }^{30}$ words of Jesus from the Gospel of Matthew: oủx $\dot{\omega} \varsigma$ $\dot{\gamma} \gamma \dot{\omega} \theta \dot{\varepsilon} \lambda \omega$, $\dot{\alpha} \lambda \lambda^{\prime} \dot{\omega} \varsigma \sigma^{31}$ makes Bessarion convinced that God does not approve of immoderate laments. People cannot comprehend His ideas and decisions, so they should accept them. Theodora's death should be regarded as the act of supreme mercy, because death is not an evil, on the contrary, it makes one free from earthly cares and leads to salvation. In the consolatory apostrophe addressed to the Emperor Alexius IV Bessarion argues that, even though his wife's death is painful for him, he should treat this suffering as if it were a paternal admonishment. Abraham, Job, David proved that the way to sanctity leads through difficulties. Above all, Alexius should follow David's example. I would like to point out that the consolation found in the second monody is

\footnotetext{
${ }^{27}$ Bessarion, I, 536, 24.

${ }^{28}$ Bessarion, II, 363, 10.

${ }^{29}$ Bessarion, II, 365, 11-12.

${ }^{30}$ BeSSARION, II, 354, 27-28; II, 355, 6-7.

${ }^{31}$ Mt 26, 39.
} 
more complex in structure. The parenetical tone of the argument, performed with a dialectical technique of an experienced rhetor, changes in the final part of the monody, in which the laudation of the Empress reappears.

The purely poetic elements of the poems should be also taken into consideration. The way in which the author depicts various images and gives them meaning are worthy of deeper analysis. In the second monody Bessarion recalls the motif of Christ's crucifixion, but describes the drops of blood and sweat falling down his face in only a few words ${ }^{32}$. From the whole story of the Passion of Lord Bessarion chose only one small detail and made it a symbol of the suffering and sacrifice of Christ, as if he tried to spotlight a small part of a much bigger canvas. The 'verbal' picture, reduced to a minimum, leaves additional space for the recipients' imagination, and even more so as the author makes the tormented Jesus speak

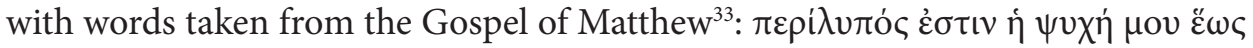
$\theta a v a$ tov ${ }^{34}$, changing at the same time the chronology of the events. According to the Evangelist the words were originally spoken by Jesus to his disciples in the Gethsemane garden before he was apprehended by the Roman soldiers. It is less than probable that Bessarion made a mistake. This part of the poem must rather be considered as intended by the author, especially when we realise the fact that in this part of the monody he quotes the prayer of Christ twice: oủx $\dot{\omega} \varsigma \dot{\varepsilon} \gamma \dot{\omega} \theta \dot{\varepsilon} \lambda \omega$, $\dot{\alpha} \lambda \lambda^{\prime} \dot{\omega} \varsigma \sigma v^{35}$, that we find in the same chapter of the Gospel ${ }^{36}$. Bessarion's evident parachronism seems to have been treated as a particular technique of poetic collage. It is even more meaningful in the light of the content of the evoked chapters of the Gospel dedicated to the spiritual suffering of Christ. By the way, it is worth noticing that a similar technique was used as early as by Pindar.

A picture painted with equally few words appears in the final part of the second monody, in which Bessarion gives his vision of paradise - the final destina-

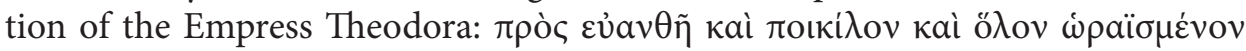

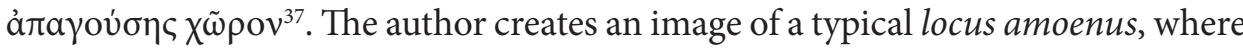
the recipients of his poem may see a colour-hued grassland, full of lush vegetation, that sparkles with multi-coloured flowers and stuns them by its wondrous scent. It is worth emphasising here, that the topos of locus amoenus derives directly from the times of Homer and has a long poetic tradition ${ }^{38}$.

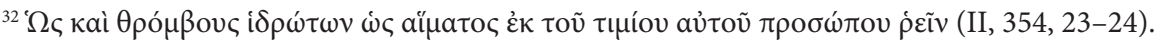

${ }^{33}$ Mt 26, 38.

${ }^{34}$ Bessarion, II, 354, 25.

${ }^{35}$ Bessarion, II, 354, 27-28; II, 355, 6-7.

${ }^{36}$ Mt. 26, 39.

${ }^{37}$ Bessarion, II, 359, 5-6.

${ }^{38}$ Cf. e.g. G. SснӧNBEck, Der locus amoenus von Homer bis Horaz, Heidelberg 1962; P. Hass, Der locus amoenus in der antiken Literatur. Zu Theorie und Geschichte eines literarischen Motivs, Bamberg 1998, p. 4 sqq; B.S. Haller, Landscape Description in Homer's Odyssey, Pittsburgh 2007 [Ph.D. diss.];
} 
A particular kind of poetic image is reached in monodies by a stylistic device rooted in archaic Greek poetry, which is called hypomnesis. In the first monody Bessarion evokes the image of Theodora and the timbre of her voice as preserved in the memory of the Emperor. There is also another reminiscence of Alexius that is in evident contrast with the previous one: the act of lifting the tombstone, under which the Empress was going to be buried ${ }^{39}$. Thus, in only these two short sentences Bessarion included a surprising effect of hypomnesis - one scene was taken from the life of the Empress and one from her funeral. The memories from the funeral celebrations reappear in the third monody, in which Bessarion describes the procession of lamenting mourners: the Emperor and the officials, women and men, the rich and the poor. Furthermore, all the actions take place in the light

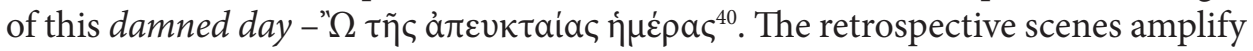
the number of the means of poetic expression and let the author diversify the conventional elements of laudatio and comploratio to avoid monotony.

The metaphors, used very moderately by Bessarion, remain within the typical for funeral forms. Such metaphors as e.g. the depth of misery, $\beta a \theta \dot{v} \varsigma \kappa \alpha \kappa \tilde{\omega} v^{41}$,

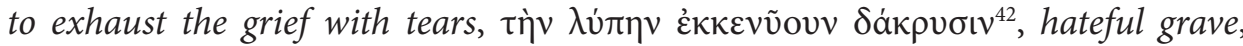

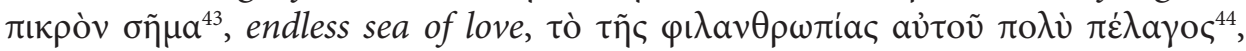

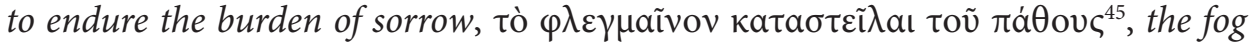

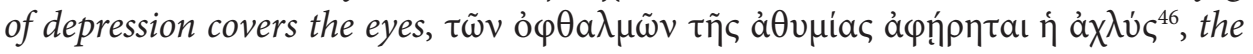

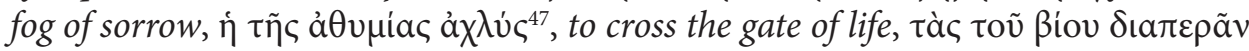
$\pi \dot{\lambda} \lambda a \varsigma^{48}$, cannot be perceived as an expression of exaltation, but they rather inform about the sensibility and imagination of a young writer. On the other hand

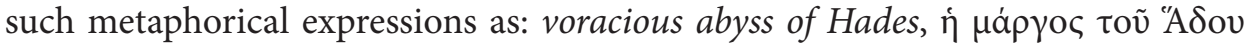

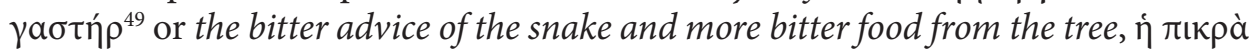

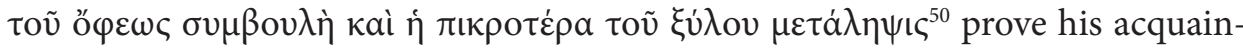
tance with cultural tradition, his erudition and openness for the symbiosis of spirituality of the pagans and the Christians.

S. SAÏD, Topos and Topoi, [in:] A Companion to Greek Literature, ed. M. Hose, D. Schenker, Malden-Oxford-Chichester 2016, p. 353-369.

${ }^{39}$ Bessarion, I, 532, 22-25.

${ }^{40}$ Bessarion, III, 366, 16-21.

${ }^{41}$ Bessarion, II, 352, 2.

${ }^{42}$ Bessarion, II, 352, 3.

${ }^{43}$ Bessarion, II, 352, 20.

${ }^{44}$ Bessarion, II, 353, 22.

${ }^{45}$ Bessarion, II, 359, 15-16.

${ }^{46}$ Bessarion, II, 359, 17-18.

${ }^{47}$ Bessarion, III, 368, 7.

${ }^{48}$ Bessarion, III, 364, 4-5.

${ }^{49}$ Bessarion, II, 353, 27-28.

${ }^{50}$ Bessarion, III, 364, 1-2. 
The comparisons, though rare in the texts, are also worth consideration. To give an example: human existence is compared to sailing the sea during calm, when the winds are fair; dangerous; when one strays from the course and ploughs into the rocks ${ }^{51}$. Or the Empress, for the goodness of her heart, her mercy and concern about the people, is compared to a bird that embosoms the nestlings with its wing, giving them comfort and safety ${ }^{52}$.

Finally, I would like to refer to the intertextual links as an important element of artistic work, according to the aesthetic norms of poesis docta. Their presence and value were appreciated by F.M. Pontani ${ }^{53}$. The Italian scholar prepared an index of all links, both the apparent ones and the suggested allusions, so enlisting them here would be superfluous. Therefore, I am going to mention only some minor nuances concerning the issue. In the beginning of the first monody $\mathrm{y}^{54} \mathrm{Bessa}-$ rion refers twice to Hecuba, the tragedy by Euripides ${ }^{55}$. It is not a coincidence if we realise that Hecuba is a tragedy based on human suffering and mourning for the dead. Bessarion seems to have noticed an analogy between the plot of the Greek drama and the contemporary circumstances. Thus, he referred to the literary experienced recipients of his monody, and with such associations he managed to enhance the emotions that were stated expressis verbis.

The second monody can be characterised by diachronic variations of references: to Homer, to the Old and New Testament and finally to John Chrysostom, one of the early Greek Church Fathers. The quotation taken from the Odyssey: But tell me of your family, since you did not spring from a tree or a stone as in the ancient tales ${ }^{56}$ seems an interesting issue to discuss. These are Penelope's words to Odysseus, she is unaware of the fact that she is talking to her husband. She smply wants to find out who the stranger is and where he comes from. In this context the words have great meaning: you cannot be from nowhere. We have literary evidence that this saying was already in proverbial use in the $4^{\text {th }}$ century, but it had a different meaning: you are not as strong as an oak, neither as tough as a rock ${ }^{57}$.

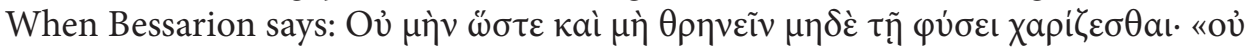

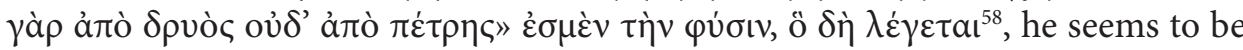
referring to the latter meaning of this phrase: we are not strong and tough enough to refrain from despairing. If we look at the quotation from a broader perspective

\footnotetext{
${ }^{51}$ Bessarion, I, 533, 22-26.

${ }^{52}$ Bessarion, II, 352, 12-14

${ }^{53}$ F.M. Pontani, op. cit., p. 106, 108-110.

${ }^{54}$ Bessarion, I, 531, 8-9; I, 532, 12.

${ }^{55}$ EURIPIDES, Hecuba, v. 660; 1121.

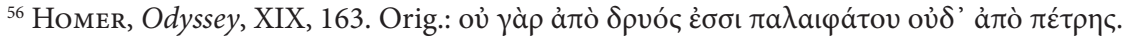

${ }^{57}$ On the semantic transformations of Homer's adages, see H. ZALEwsKA-JurA, Jak Palladas $z$ Homera żartowat, [in:] Humor. Teorie - praktyka - zastosowania. Zrozumieć humor, vol. II.1, Piotrków Trybunalski 2009, p. 177-182.

${ }^{58}$ Bessarion, II, 354, 4-5.
} 
the first possible meaning is also likely to be accepted we cannot be from nowhere as we are from here, from Trebizond, just like our Empress. It was Bessarion's way to combine two different cultural codes: the one rooted in the oldest literature and the contemporary one in the form of a proverb, by pointing out the double meaning of the phrase.

Another Greek concept, that the best thing for a man is not to be born, and if already born, to die as soon as possible, appears in the beginning and in the final part of the third monody ${ }^{59}$ and makes the monody a whole. According to ancient tradition these words were attributed to Silenus, who said them to the Phrygian King Midas, after being seized by the king's servants ${ }^{60}$. The reason why Bessarion made reference to this pagan idea and made it an important element of his composition is a matter to be put under question. Perhaps he referred to Sophocles and his nostalgic third stasimon found in Oedipus at Colonus, in which the old dramatist, reconciled with the approaching doom, says goodbye to his life ${ }^{61}$. It is conceivable then that in Bessarion's opinion the idea it is better not to be born at all that appears twice in the poem is a veiled way of expressing his resignation and reconciliation with the fate, which would correspond with the calmer atmosphere of the third epicedium in comparison with the explosion of despair observed in the first poem.

The analyses of the monodies on the death of Theodora Comnena were aimed at pointing out the significant artistic value of the poetry written by young Bessarion. He is certainly a considerable, very sensitive, well read and extraordinarily intelligent author. Moreover, he addressed his poems to elite and erudite recipients. He followed the accepted intellectual and literary norms and wrote his poems in classical Greek, which by then was distorted in everyday use, not to say, degraded. Hence, the sense of artificiality and mannerism may be a natural consequence of the language he used. His poetry was undoubtedly influenced by the rhetorical and intellectual legacy of Hellas, but it also followed the dominant literary trends of those times. Bessarion was fully aware of his readers' tastes, preferences, expectations and artistic sensitivity, and these elements mainly effected and determined the character of his poetry. Despite various customary and cultural aspects of the Byzantine époque, we cannot forget about these circumstances. Bessarion's reception and evaluation in modernity is open to discussion; contemporary readers have other cultural background, literary experiences, different sensitivity and aesthetic perception. Certainly, the group of potential recipients of this poetry with necessary cognitive skills (apart from language competences) is considerably limited when compared to Byzantine times. His poetry may as well be appreciated or undervalued according to subjective tastes, but it must be regarded as a precious cultural artefact of the $15^{\text {th }}$-century Byzantine Empire.

\footnotetext{
${ }^{59}$ Bessarion, III, 364, 3-5; III, 367, 6-8.

${ }^{60}$ This version of the legend was spread by Herodotus (The Histories, VIII, 138).

${ }^{61}$ Sophocles, Oedipus at Colonus, v. 1224-1227.
} 


\section{Bibliography}

\section{Sources}

Gentilini A., Una consolatoria inedita del Bessarione, [in:] Scritti in onore di Carlo Diano, Bologna 1975, p. 149-164.

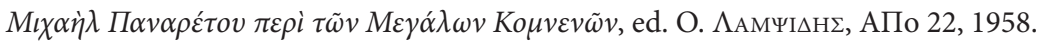

Sideras A., 25 Unedierte byzantinische Grabreden, Thessalonica 1990.

Sideras A., Die byzantinischen Grabreden: Prosopographie, Datierung, Überlieferung, Wien 1994.

\section{Secondary literature}

Bandini A., De vita et rebus gestis Bessarionis cardinalis Nicaeni. Commentarius, Romae 1777.

Coluccia G.L., Basilio Bessarione. Lo spirito Greco e l'occidente, Firenze 2009.

»Inter Graecos latinissimus, inter Latinos graecissimus«. Bessarion zwischen den Kulturen, ed. C. MARTL, C. KAISER, T. RickLIN (Pluralisierung \& Autorität, 39), Berlin 2013.

Haller B.S., Landscape Description in Homer's Odyssey, Pittsburgh 2007 [Ph.D. diss.].

Hass P., Der locus amoenus in der antiken Literatur. Zu Theorie und Geschichte eines literarischen Motivs, Bamberg 1998.

Jurewicz O., Historia literatury bizantyńskiej. Zarys, Wrocław 1984.

Laвowsky L., Bessarion's Library and the Biblioteca Marciana, Rome 1979.

Mohler L., Kardinal Bessarion als Theologe, Humianist und Staatsman, vol. I-III, Paderborn 1923-1942.

Monfasani J., Bessarion Scholasticus. A study of cardinal Bessarion's Latin library, Turnhout 2012.

Pontani F.M., Epicedi inediti del Bessarione, RSBN 5, 1968, p. 105-121.

Ronchey S., Bessarione poeta e l'ultima corte di Bisanzio, [in:] Bessarione e l'Umanesimo. Catalogo della mostra (Venezia, Biblioteca Nazionale Marciana, 27 Aprile - 31 Maggio 1994), ed. G. FIACCADORI, Napoli 1994, p. 47-65.

SAFFrey H.-D., Recherches sur quelques autographes du cardinal Bessarion et leur caractère autobiographique, [in:] Mélanges Eugène Tisserant, vol. III, Cité du Vatican 1964, p. 279-292.

SAÏD S., Topos and Topoi, [in:] A Companion to Greek Literature, ed. M. Hose, D. Schenker, Malden-Oxford-Chichester, p. 353-369.

Salamon M., Bessarion, [in:] Religia. Encyklopedia PWN, vol. II, Warszawa 2001, p. 47.

Sснӧnвеск G., Der locus amoenus von Homer bis Horaz, Heidelberg 1962.

Stormon E.J., Bessarion before the Council of Florence. A survey of early writings (1423-1437), [in:] Byzantine Papers. Proceedings of the First Australian Byzantine Studies Conference, Canberra, 17-19 May 1978, ed. E. Jeffreys, M. Jeffreys, A.M. Moffatt, Canberra 1981, p. 128-156.

Tацвот A.-M., Bessarion, [in:] ODB, vol. I, p. 285.

Vast H., Le cardinal Bessarion (1403-1472). Étude sur la Chrétienté et la Renaissance vers le Milieu du XV siècle, Paris 1878.

Wellesz E, Historia muzyki i hymnografii bizantyjskiej, trans. M. KAZIŃsKi, Kraków 2006.

ZABŁocki S., Antyczne epicedium i elegia żałobna. Geneza i rozwój, Warszawa 1965. 
Zalewska-Jura H., Jak Palladas z Homera żartowat, [in:] Humor. Teorie - praktyka - zastosowania. Zrozumieć humor, vol. II.1, Piotrków Trybunalski 2009.

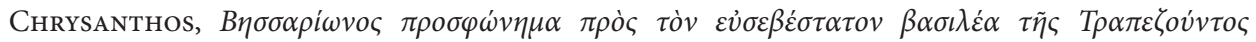

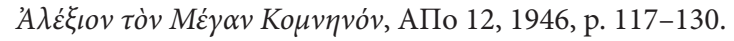

КАрПов С.П., История Трапезундской Империи, Санкт-Петербург 2007.

Abstract. This article discusses the relatively unknown poetry of Bessarion, the future Cardinal. The author argues with a negative opinion of F.M. Pontani concerning the three epicedia on the death of Theodora Comnena. The author analyses the composition, artistic means of expression and intertextual links in order to revise the common opinion in the subject and to prove the presence of literary values in the mentioned poems.

Keywords: Bessarion, Trebizond, Trabzon, Comneni, Theodora Comnena, Byzantine empire, empire of Trebizond

Hanna Zalewska-Jura

Katedra Filologii Klasycznej

Wydział Filologiczny

Uniwersytet Łódzki

ul. Pomorska 171/173

90-236 Łódź, Polska/Poland

hannajura@o2.pl 